\title{
Czy pierścień naczyniowy był przyczyną duszności?
}

\section{Was vascular ring the cause of dyspnea?}

Praca nie była finansowana.

Ostatnio w „Pneumonologii i Alergologii Polskiej” ukazał się artykuł zatytułowany „Ring naczyniowy - rzadka przyczyna duszności u pacjenta w podeszłym wieku" [1]. Uważna lektura rodzi duże wątpliwości, czy tytuł ten jest adekwatny do przedstawionej sytuacji klinicznej. Niestety, przypadek opisano zbyt powierzchownie, pomijając wiele istotnych informacji. Aby ustalić czy duszność spowodowana była pierścieniem naczyniowym, autorka powinna odpowiedzieć na wiele pytań. Krótkiego komentarza wymaga 5 problemów.

\section{Serce}

Konieczne jest odróżnienie płucnych i sercowych przyczyn duszności. Z opisu przypadku wiadomo, że chory na chorobę niedokrwienną serca z zaburzeniami rytmu serca i z blokiem lewej odnogi pęczka Hisa zgłaszał pogłębiającą się duszność [1]. Nie określono jednak, jaki miała ona charakter i przebieg. Czy wiązała się z wysiłkiem? Czy występowała w spoczynku? Czy pojawiała się w pozycji leżącej? Jak była sklasyfikowana w skali MRC? Czy obserwowano obrzęki kończyn dolnych lub objaw wątrobowo-szyjny? Jaka była czynność serca i ciśnienie tętnicze? Jakie leki stosowano? Pytania te są ważne, gdyż na zdjęciu radiologicznym klatki piersiowej widać powiększoną sylwetkę serca (szczególnie prawa komora) oraz poszerzone są wnęki, prawdopodobnie naczyniowo, z zaznaczonymi szczelinami międzypłatowymi. Sugeruje to niewydolność krążenia. Wskazane jest wykonanie echokardiografii z określeniem frakcji wyrzutowej, wielkości jam serca, kurczliwości mięśnia i stanu zastawek. Istotna jest również ocena ciśnienia w tętnicy płucnej. Warto też wiedzieć, jaka jest wartość NT-proBNP, gdyż pozwoli to określić na ile duszność wiąże się $\mathrm{z}$ wysoce prawdopodobną $\mathrm{w}$ tym przypadku niewydolnością serca.

\section{Płuca}

Jeszcze większe wątpliwości budzi ocena płucnej komponenty duszności. Obraz radiologiczny, niezależnie od cech niewydolności krążenia, sugeruje rozedmę płuc. Świadczą o tym nadmierne przejaśnienie górnych pól płucnych, niskie ustawienie przepony, beczkowata klatka piersiowa i zwiększenie zamostkowej przestrzeni powietrznej. Na zdjęciu w projekcji tylno-przedniej nie są widoczne w całości kąty przeponowo-żebrowe, co utrudnia interpretację. U otyłego chorego widać płaskie ustawienie kopuły przepony, a otyłość zwykle powoduje jej uniesienie. Upowietrznienie płuc można lepiej ocenić w tomografii komputerowej, ale w artykule przedstawiono jedynie skany w oknie śródpiersiowym.

Rozedmę płuc sugeruje także wynik spirometrii. Może o tym świadczyć zmniejszenie VC (vital

\footnotetext{
Address for correspondence: dr hab. n. med. Tadeusz M. Zielonka, Katedra i Zakład Medycyny Rodzinnej WUM, 02-097 Warszawa, ul. Banacha 1a, tel./faks: 22 3186325, e-mail: tadeusz.zielonka@wum.edu.pl

DOI: 10.5603/PiAP.2015.0027

Received: 22.01.2014

Copyright ( 2015 PTChP

ISSN 0867-7077
} 
capacity) i tak zwana „pułapka powietrzna”, czyli większa wartość wdechowej pojemności życiowej (FIVC [forced inspiratory vital capacity] 2,95 l) w stosunku do wydechowej (FEVC [forced expiratory vital capacity] 2,8 l). Zmniejszenie pojemności życiowej w tym przypadku może być spowodowane otyłością. Wskazane jest wykonanie badania pletyzmograficznego. Nie można bowiem wykluczyć restrykcji (ze zmniejszeniem TLC [total lung capacity]), nadmiernego upowietrznienia płuc (ze zwiększeniem RV [residual volume]) ani zmian mieszanych (wzrostu RV i zmniejszenia TLC). Równie ważne jest wykonanie próby rozkurczowej z oceną spirometryczną po podaniu krótkodziałającego leku rozszerzającego oskrzela. Zaleca się to przy wykryciu obturacji oskrzeli i stwierdzeniu pułapki powietrznej [2].

Autorka nie określiła, czy chory palił papierosy. Wynik spirometrii zawiera informację, że badany jest niepalący, ale nie wyklucza to nikotynizmu w przeszłości. Analizując dane kliniczne, radiologiczne i czynnościowe układu oddechowego, można wysunąć podejrzenie przewlekłej obturacyjnej choroby płuc (POChP). Konieczne jest zatem zdefiniowanie czynników ryzyka rozwoju tej choroby, a zwłaszcza nikotynizmu i narażenia zawodowego. Czy chory zgłaszał kaszel? Jeśli duszność była wywołana uciskiem na tchawicę, mógł być słyszalny stridor. Wraz ze świstami i bezdechem należy on do typowych objawów zwężenia w górnym odcinku dróg oddechowych spowodowanego anomaliami naczyniowymi [3]. Czy szmer pęcherzykowy był prawidłowy, czy może ściszony? Czy występowały dźwięki dodatkowe - świsty lub furczenia (jak w chorobach obturacyjnych oskrzeli), a może trzeszczenia sugerujące niewydolność serca? Czy obserwowano tachypnoe? U chorego z dusznością niezbędna jest ocena wydolności układu oddechowego. Absolutne minimum stanowi pomiar $\mathrm{SaO}_{2}$, ale należało wykonać badanie gazometryczne z pomiarem $\mathrm{PaO}_{2}$ i $\mathrm{PaCO}_{2}$.

Największe zastrzeżenia budzi interpretacja wyniku badania spirometrycznego. Autorka stwierdziła obturację dróg oddechowych u chorego z dusznością oraz $\mathrm{z}$ anomalią naczyniową i pochopnie połączyła wszystkie te elementy w jedną całość. Jeśli zmiany w badaniu spirometrycznym spowodował ucisk tchawicy przez pierścień naczyniowy, byłaby to tak zwana „obturacja poza klatką piersiową" wynikająca ze zmian w górnym odcinku dróg oddechowych. Charakteryzuje się ona ograniczeniem przepływu wdechowego i wydechowego (ryc. 1) [4]. Stosunek $\mathrm{MEF}_{50} / \mathrm{MIF}_{50}$ nierzadko $w$ tych przypadkach jest $>1$, podczas gdy u chorego wynosił on 0,3. Typowy jest także płaski kształt krzywej przypływów wdechowo -wydechowych, niejednokrotnie przebiegającej równolegle do osi X [4, 5]. U chorego stwierdzono zmniejszające się przepływy w drobnych oskrzelach - PEF (peak expiratory flow) 66\%, $\mathrm{MEF}_{75}$ (maximal expiatory flow) 46\%, $\mathrm{MEF}_{50} 30 \%$, $\mathrm{MEF}_{25} 17 \%$ (przy $\mathrm{FEV}_{1}$ [forced vital capacity in one second] $62 \%$, a VC 66\%). Jak mechaniczny ucisk na tchawicę mógł ograniczyć przepływ obwodowy i spowodować pułapkę powietrza, stwierdzaną przy zmniejszeniu ciśnienia okluzji wynikającym z utraty sprężystości płuc? Obturacja powodowana uciskiem tchawicy zwykle nie reaguje na leki rozszerzające oskrzela, stąd tak ważne było wykonanie próby rozkurczowej. Warto porównać krzywą wdechowo-wydechową przepływ-objętość u chorych z podobnymi zmianami naczyniowymi, u których prawidłowej wartości $\mathrm{FEV}_{1}$ towarzyszyło znaczne zmniejszenie PEF, bardzo typowe dla obturacji poza klatką piersiową [6].

Rozpoznanie pierścienia naczyniowego dopiero w 71. roku życia budzi poważną wątpliwość, czy był on powodem duszności. Jest to wada wrodzona, która częściej wywołuje obturację w okresie niemowlęcym, kiedy drogi oddechowe są bardziej elastyczne, niż w wieku podeszłym, gdy są sztywniejsze. Tak późne wykrycie zaburzenia przemawia za inną przyczyną duszności. Wśród 35 chorych z podobną wadą naczyniową w Korei, u 70\% anomalię rozpoznano w okresie noworodkowym [7]. Chociaż obturację dróg oddechowych u osób z anomaliami naczyniowymi stwierdzano $\mathrm{w}$ podeszłym wieku, to jednak u tych chorych od wielu lat występowały objawy astmatyczne [8]. Obturacja dróg oddechowych opisywana u chorych z nieprawidłowym przebiegiem dużych naczyń niejednokrotnie wiązała się z uciskiem na oskrzela główne a nie na tchawicę [3, 8]. Warto pamiętać o nawracających infekcjach układu oddechowego, jakie mogą towarzyszyć pierścieniowi naczyniowemu, co u dzieci może sugerować obecność ciała obcego w oskrzelach [9]. Nierzadko omawiane zmiany naczyniowe nie powodują żadnych objawów [10]. W dużych zestawieniach ucisk dróg oddechowych przez nieprawidłowe naczynia był stwierdzany jedynie u 13\% dorosłych chorych i u 26\% dzieci [3]. Stąd duszność zgłaszana przez pacjenta mogła nie być spowodowana anomalią rozwojową dużych naczyń. Trudno doszukiwać się związku przyczynowo-skutkowego w opisanym przypadku pomiędzy dusznością, obturacją dróg oddechowych a stwierdzonym 


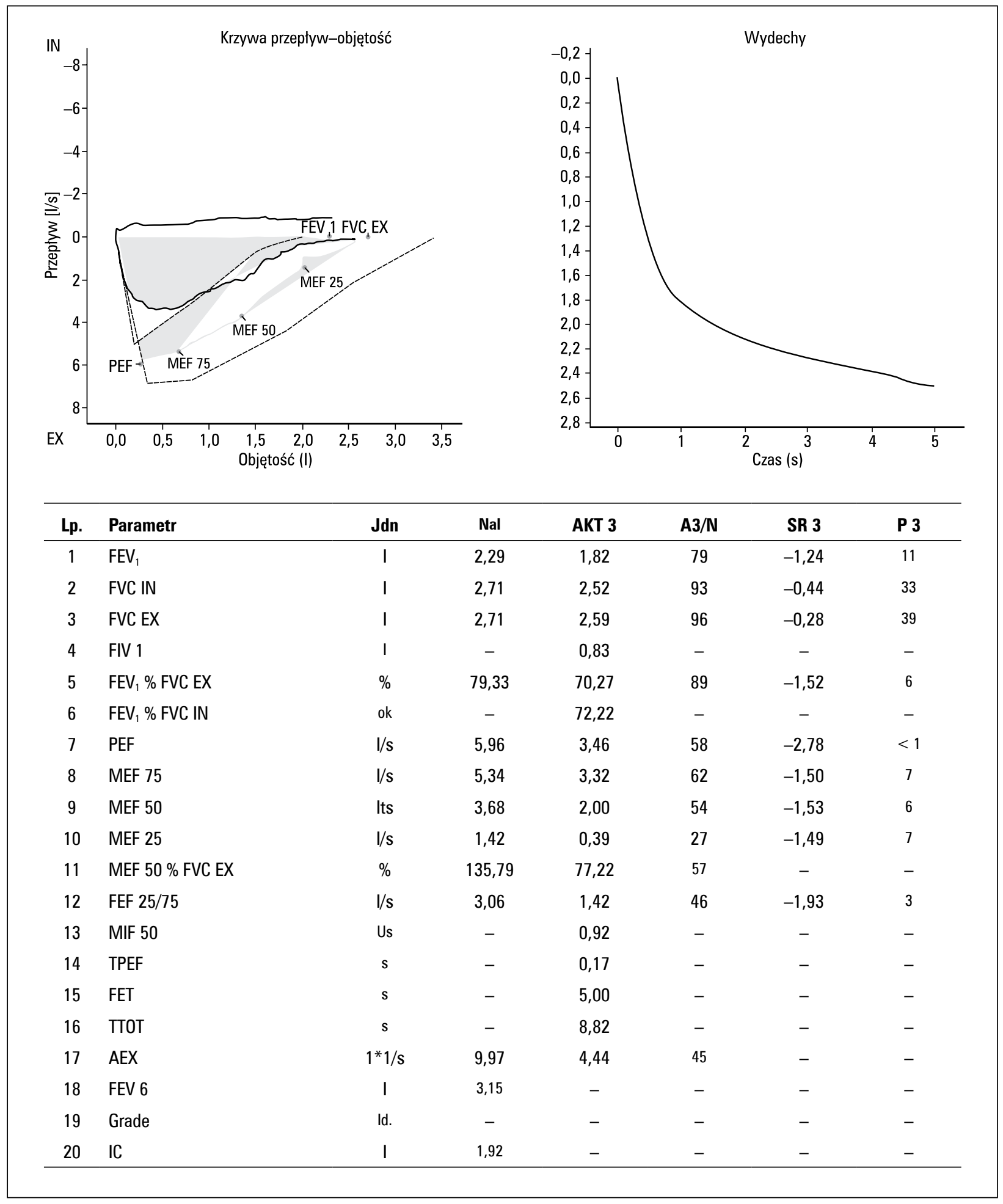

Rycina 1. Obraz obturacji górnych dróg oddechowych w badaniu spirometrycznym u 55-letniej chorej z porażeniem strun głosowych Figure 1. Upper respiratory tract obturation in spirometry of a 55 year old patient with paralysis of chorda vocalis

w komputerowym badaniu tomograficznym pierścieniem naczyniowym. Uważna i dokładniejsza ocena układu krążenia i oddechowego pozwoli wyjaśnić, co tak naprawdę powodowało duszność u chorego.

\section{Przełyk}

Warto zapytać także o objawy z górnego odcinka przewodu pokarmowego. Czy chory zgłaszał dysfagię lub wymioty? Jaki miał apetyt i czy 
nie schudł? Pierścień naczyniowy powodujący zwężenie tchawicy często ucisku także przełyk. Tchawica posiada elementy chrzęstne, które stabilizują jej światło. Nie ulega ona tak łatwo uciskowi przez naczynia krwionośne i obturację zwykle powoduje więzadło uciskające jej błoniastą część [3]. Nierzadko dochodzi do zwężenia, a nawet do zamknięcia światła przełyku przez pierścień naczyniowy. $\mathrm{W}$ materiale koreańskim objawy gastryczne stwierdzono u 29\% chorych (oddechowe u 45\%), ale ucisk przełyku był widoczny u 57\%, a dróg oddechowych u 60\% [7]. Trzeba zainteresować się wpływem zmian naczyniowych na przewód pokarmowy, gdyż mogą one spowodować wymioty i niedożywienie.

\section{Otyłość}

Analizując potencjalne przyczyny duszności, nie można $\mathrm{w}$ tym przypadku pominąć otyłości. $\mathrm{Z}$ wyniku badania spirometrycznego wiadomo, że pacjent ważył $114 \mathrm{~kg}$ przy wzroście $176 \mathrm{~cm}$ (BMI [body mass index] 36,8). Nic dziwnego, że chory w podeszłym wieku z problemami kardiologicznymi i tak znaczną otyłością odczuwał duszność w trakcie wysiłku, a obserwowane zmiany naczyniowe nie musiały się do tego przyczynić.

\section{Aspekty etyczno-prawne}

Niezależnie od oceny klinicznej przedstawionego przypadku, trzeba także zwrócić uwagę na prawo obowiązujące w Unii Europejskiej. Zgodnie z Dyrektywą Unijną z 1995 r. i wynikającą z niej Ustawą o ochronie danych osobowych z $1997 \mathrm{r}$. bez zgody chorego nie można umieścić jego imienia, nazwiska, daty urodzenia i PESEL w tekście artykułu o charakterze naukowym lub dydaktycznym [11, 12]. Skopiowany wynik badania spirometrycznego zawiera wszystkie te dane wraz $\mathrm{z}$ informacjami o jego stanie zdrowia $\mathrm{w}$ tekście artykułu. Jest to rażące naruszenie prawa i zasad deontologicznych. Wynika to z braku głębszej refleksji środowisk medycznych nad znaczeniem tajemnicy lekarskiej w praktyce. Po 18 latach obowiązywania w Polsce Ustawy o ochronie danych osobowych lekarze nie zawsze się do niej stosują, nie wszyscy ją znają i rozumieją. Pomimo precyzyjnych zapisów prawnych i etycznych, tak częste jest ich naruszanie, że wielu lekarzy nie zauważa działań niezgodnych z prawem i Kodeksem Etyki Lekarskiej. Do Głównego Inspektora Ochrony Danych Osobowych wpływa wiele skarg na naruszanie przepisów o ochronie danych w służbie zdrowia. Nie przestrzeganie prawa może spowodować przykre konsekwencje. Może zamiast frazesów o tajemnicy lekarskiej i przysiędze Hipokratesa warto poważnie traktować przepisy prawa w zakresie ochrony danych osobowych.

Reasumując, warto aby autorka pogłębiła naszą wiedzę o chorym i wykonała wskazane badania. Być może po uzyskaniu wyników okaże się, że przyczyny duszności były bardziej złożone niż to sugerowano. Weryfikacja rozpoznań pozwoli skuteczniej leczyć chorego i dzięki kompleksowemu postępowaniu zmniejszyć duszność.

\section{Konflikt interesów}

Autor nie zgłasza konfliktu interesów.

\section{Piśmiennictwo}

1. Orwaldi M. Ring naczyniowy — rzadka przyczyna duszności u pacjenta w podeszłym wieku. Opis przypadku. Pneumonol. Alergol. Pol. 2015; 83: 55-59.

2. Zalecenia Polskiego Towarzystwa Chorób Płuc dotyczące wykonywania badań spirometrycznych. Pneumonol. Alergol. Pol. 2006; 74 (Supl. 2): 1-44.

3. Valletta EA, Pregarz M, Bergamo-Andreis IA, Boner AL. Tracheoesophageal compression due to congenital vascular anomalies (vascular rings). Pediatr. Pulmonol. 1997; 24: 93-105.

4. Pellegrino R, Viegi G, Brusach V. i wsp. Interpretative strategies for lung function tests. Eur. Respir. J. 2005; 26: 948-968.

5. Zielonka TM. Warsztaty spirometryczne - kształt krzywej przepływ-objętość. Medycyna po Dyplomie 2006; 15: 128-131.

6. Lastra LP, Pimiento AP, Sánchez LA, Mosquera MR, Cubero AG. Be sure you are treating asthma. Allergol. Immunopathol. (Madr.) 2006; 34: 127-128.

7. Suh YJ, Kim GB, Kwon BS. i wsp. Clinical course of vascular rings and risk factors associated with mortality. Korean Circ. J. 2012; 42: 252-258.

8. Miyamoto Y, Ohashi A, Ishi H, Tazaki G, Kondo T. A case of severe bronchial stenosis caused by a vascular ring in an elderly woman. Nihon Kokyuki Gakkai Zasshi 2008; 46: 243-247.

9. Pumberger W, Voitl P, Göpfrich H. Recurrent respiratory tract infections and dysphagia in a child with an aortic vascular ring. South Med. J. 2002; 95: 265-268.

10. Nazeri A, Sohawon S, Noordally SO. An asymptomatic left pulmonary artery sling and a right supernumerary tracheal bronchus. ANZ J. Surg. 2011; 81: 305-306.

11. Dyrektywa 95/46/EC Parlamentu Europejskiego i Rady z dnia 24 października 1995 roku w sprawie ochrony osób fizycznych w zakresie przetwarzania danych osobowych oraz swobodnego przepływu tych danych.

12. Ustawa o ochronie danych osobowych z dnia 26 października 1997. Dz. U. 1997 nr 133 poz. 883. 